\title{
SUFISME SEYYED HOSSEIN NASR DAN FORMALISME AGAMA DI INDONESIA
}

\author{
Irfan Noor \\ Fakultas Ushuluddin IAIN Antasari Banjarmasin \\ HP. 081331336942 / Email: irfannoor@iain-antasari.ac.id
}

\begin{abstract}
The growing phenomenon of politics identity after the 1998 reform, which tends to encourage "religious communalism", should be a major concern and this should be answered by the discipline of Islamic philosophy as the challenges in building a better Indonesian nation with a better future. In this context, Seyyed Hossein Nasr's thought is relevant to be actualized as the effort to contextualize the role of Islamic philosophy for contemporary society and as an approach to understand the reality of religion through the world-view of Sufism.
\end{abstract}

Kata-kunci: Komunalisme Agama, Spiritualisme, Hirakhi Realitas, dan Asal Yang Ilahi.

\section{Pendahuluan}

Perjalanan transisi demokrasi pasca Orde di Indonesia telah banyak menumbuhkan harapan positif dalam kehidupan berbangsa. Namun sayangnya, seiring dengan perjalanan transisi demokrasi tersebut juga tumbuh politik identitas dengan hadirnya kelompok-kelompok Islam yang memiliki agenda "Islamisasi ruang publik kebangsaan" secara keras bahkan tanpa kenal kompromi.

Dengan munculnya fenomena politik identitas seiring dengan perjalanan proses transisi demokrasi di ranah kebangsaan kita saat ini, maka bertolak belakang dengan spirit awal gerakan reformasi 1998, fenomena ini justru menjadi katalisator mainstreaming "komunalisme agama" bercorak teokratik-radikal di atas realitas masyarakat Indonesia yang pluralis dan multikultural.

Dengan demikian, tumbuhnya fenomena politik identitas yang cenderung mendorong "komunalisme agama" haruslah kita jawab sebagai tantangan dalam mengembangkan filsafat Islam agar bisa berkontribusi positif bagi pengembangan bangsa Indonesia yang lebih baik dan bermasa depan. 


\section{Politik Identitas dan Peran Sufisme Islam}

Reformasi sistem pemerintahan dalam transisi demokrasi bisa saja mengalami "arus balik". Menurut Lipset ${ }^{1}$ dan O'Donnell dan Schmitter, pemerintahan baru yang berada dalam proses transisi demokrasi dari sistem pemerintahan otoriter ke sistem pemerintahan demokratis cenderung tidak memiliki stabilitas dengan legitimasi yang kuat di masyarakat. O'Donnell dan Schmitter bahkan mengingatkan bahwa transisi demokrasi adalah "perubahan dari satu rezim otoriter menuju 'wajah yang lain' yang belum jelas". "

Wajah yang lain itu bisa berwujud tegaknya sebuah demokrasi politik atau malah sebaliknya. Artinya, sejalan dengan proses transisi demokrasi yang menawarkan kebebasan yang sangat luas sebagai antithesis pemerintahan otoriter masa lalu, proses transisi demokrasi -- pemerintahan baru yang memiliki ciri yang tidak stabil dan "gamang" (governmentless dan lawless) -- juga juga bisa melahirkan antithesis demokrasi dalam bentuk politik identitas yang mendorong mainstreaming "komunalisme agama" sebagai representasi euforia kebebasan yang berjalan bebas tanpa adanya kontrol dari negara.

Dengan demikian, "arus balik" yang bisa kita saksikan dalam kurun waktu pasca reformasi 1998 adalah maraknya gerakan Islam global atau yang akhir-akhir ini sering disebut sebagai "Gerakan Islam Transnasional" (lintas negara). ${ }^{4}$ Gerakan ini cenderung berafiliasi pada ideologi Islam beraliran salafisme khas abad $20,{ }^{5}$ yaitu suatu aliran gerakan Islam yang tidak hanya menekankan pemurnian keagamaan semata, tapi menjadi ideologi perlawanan terhadap berbagai paham yang tidak sesuai dengan nilai-nilai agama, seperti modernisme, sekularisme, kapitalisme, dan lain-lain. ${ }^{6}$ Tokoh-tokohnya antara Baltimore.

${ }^{1}$ Lipset, Seymour Martin. (1981). Political man; The social bases of politics. Maryland:

${ }^{2}$ O’Donnell, Guillermo \& Philippe C Schmitter. (1986). Transitions from authoritarian rule. Baltimore: The Johns Hopkins University Press.

${ }^{3}$ Ibid., hlm. 89.

279.

${ }^{4}$ Peter Mandaville, Global Political Islam, (London \& New York: Routledge, 2007), hlm.

${ }^{5}$ Noorhaidi Hasan, Laskar Jihad: Islam, Militancy and the Quest for Identity in Post-New Order Indonesia. (Ithaca, New York: Southeast Asia Program, Cornell University, 2006), hlm. 18.

Jamhari dan Jajang Jahroni, Gerakan Salafi Radikal di Indonesia, Jakarta: Rajawali Press, 2004), hlm. viii. Jika gerakan salafisme awal yang tampak pada gerakan Hanbali yang dipelopori oleh Abu Muhammad al-Barbahari di awal abad ke-10 menyerukan perlawanan terhadap penyimpangan keagamaan atas rasionalisme Mu'tazilah yang dipandang mengaburkan simplisitas ajaran teologi Islam dengan cara kembali kepada aqidah salaf, maka pada gerakan 
lain, Hasan Al-Banna, Sayyid Quthb (Ibkwanul Muslimin) dan Abul A'la AlMaududi (Jama'ati Islami).

Di antara gerakan Islam lintas negara yang menjadi sorotan adalah Hizbut Tahrir Indonesia, Ikhwanul Muslimin, Jundullah, Hizbullah, Majelis Mujahidin Indonesia (MMI), dan gerakan Salafi lainnya dengan beragam metamorfosisnya antara lain seperti Front Pembela Islam (FPI) (1998), Forum Komunikasi Ahlussunah Waljamaah (FKASWJ) yang kemudian melahirkan Laskar Jihad (1999).

Dari istilah "transnasional" tersebut tampak bahwa lingkup gerakan Islam ini tidak hanya terbatas pada wilayah nasional atau lokal tertentu saja, seperti Nahdhatul Ulama dan Muhammadiyah, namun melampaui sekat-sekat teritorial negara-bangsa (nation-state).

Melalui kehadiran kelompok-kelompok Islam ini diusung wacana politik identitas Islam yang mendorong agenda "Islamisasi ruang publik kebangsaan" secara keras dan cenderung tanpa kompromi untuk mencapai agenda-agenda tertentu yang berkaitan dengan pandangan dunia (world view) Islam tertentu. ${ }^{8}$ Kehadiran kelompok-kelompok Islam ini di Indonesia pasca reformasi 1998 tentu saja memunculkan mainstreaming "komunalisme agama" bercorak teokratik secara radikal" di atas realitas masyarakat yang majemuk,

kedua yang dipelopori oleh Ibnu Taimiyyah di Damaskus pada abad ke-14 menekankan pemurnian Islam dari antinomianisme dan spekulatifisme tasawuf dan tarekat yang sama sekali tidak berorientasi kepada Sunnah Nabi. Dua gerakan pemurnian berorientasi Salafisme ini kemudian diteruskan oleh gerakan pemurnian Muhammad ibn 'Abd al-Wahhab di awal abad ke-19 atas nama pemurnian syirik dan khurafat yang melawan konsep tawhid.

${ }^{7}$ Nurrohman dan Marzuki Wahid, "Politik Formalisasi Syari'at Islam dan Fundamentalisme Islam", dalam Istiqro', Vol. 01, No. 01, 2002, hlm. 45.

${ }^{8}$ Ismail Hasani, et.all., Radikalisme Agama di Jabodetabek \& Jawa Barat Implikasinya terhadap Jaminan Kebebasan Beragama/Berkeyakinan, (Jakarta: SETARA Institute, 2011).

${ }^{9}$ Radikalisme dalam sejarah Islam awal dapat ditelusuri pada gerakan kaum Khawarij yang muncul pada masa akhir pemerintahan 'Ali ibn Abî Thâlib. Langkah radikal mereka disimbolkan dengan semboyah la hukkma illâ lilllah (tidak ada hukum kecuali bagi Allah) dan la bakama illâ Allâh (tidak ada hakim selain Allah) yang dielaborasi berdasarkan QS. al-Mầidah [5]: 44 yang berbunyi: "wa man lam yablkum bimâ anzalallâh faulâika bum al kâfirûn" (siapa yang tidak menentukan hukum dengan apa yang diturunkan Allah, maka mereka adalah kafir). Karena alasan demikian, kelompok Khawarij tidak mau tunduk kepada Ali dan Mu'awiyah.

Umumnya, gerakan radikalisme Islam, di samping bersandar pada akar teologi juga menggunakan instrumen yang disebut 'jihad' yang diartikan dengan 'perang'. Konsep jihad ini sering kali dilegatimasi oleh kalangan radikalisme Islam untuk melakukan tindakan kekerasan. Alasan yang sering mendasari jihad secara teologis adalah ayat QS. Al-Baqarah [2]: 120: "Tidak. akan rela baik. Yahudi maupun Nasrani sehingga engkau tunduk kepadanya”. Ayat ini dipahami secara 
sesuatu yang sangat bertentangan dengan prinsip-prinsip demokrasi yang menjadi "spirit" awal gerakan reformasi 1998. Gagasan "komunalisme agama" yang mereka usung terkait dengan agenda kerja "pemberlakuan syari'at Islam" dalam kehidupan umat Islam dan berupaya untuk "memformalkan" syari'at Islam ke dalam batang tubuh sistem negara, yang tujuan akhirnya adalah perubahan dasar negara untuk menjadi "negara Islam" dalam pengertian kekhilafahan internasional.

Kemunculan kelompok-kelompok Islam transnasional di Indonesia pasca Orde Baru ini, memang, memancing debat terbuka di kalangan para ahli. Persoalannya, secara praktek, hampir di semua masyarakat muslim muncul anggapan bahwa agama berkaitan dengan persoalan publik. Anggapan bahwa agama hanya menjadi urusan pribadi seperti yang telah terjadi di sebagian negara di Eropa Barat, nampaknya tidak berlaku untuk masyarakat muslim. Oleh karena itu, dengan menguatnya fenomena ini di ranah kebangsaan kita saat ini, maka fenomena ini telah menandai salah satu ciri dari proses transisi demokratis yang sedang berjalan di negeri ini, dimana sebelumnya di era Orde Baru fenomena ini sangat ditabukan.

Di sini, gerakan kelompok-kelompok Islamisme itu dapat dibagi ke dalam dua tipologi, yaitu: (1) Islamisasi secara total dengan mengembalikan sistem politik ke zaman kekhalifahan Islam, yang diwakili oleh kelompok Islam Hizbut Tahrir Indonesia (HTI); (2) Islamisasi yang masih mempertimbangkan negara-bangsa Indonesia, dalam artian, bertujuan untuk membentuk negara Islam Indonesia, yang diwakili oleh kelompok Islam, seperti Laskar Jihad, Front Pembela Islam (FPI), Ikhwanul Muslimin, dan kelompok yang sejenis. ${ }^{10}$

Bersamaan dengan kehadiran kelompok-kelompok Islam ini, menurut Jamhari, berkembang wacana dan gerakan formalisasi syari'at Islam di pelbagai daerah di Indonesia. ${ }^{11}$ Munculnya wacana dan gerakan formalisasi syari'at Islam

literal bahwa orang Yahudi maupun Nasrani adalah pihak yang perlu diwaspadai karena selalu menyerang, terutama terhadap akidah umat Islam. Ayat lainnya yang juga ditengarai sebagai sumber radikalisme Islam terdapat dalam surat at-Taubah [9] ayat 29 yang artinya: "Perangilab orang-orang yang tidak beriman kepada Allab dan hari kemudian, dan tidak mengharamkan apa yang telah diharamkan Allab dan Rasul-Nya dan tidak beragama dengan agama yang benar, yaitu orang yang diberikan al Kitab kepada mereka, sampai mereka membayar jizyah, sedangkan mereka dalam keadaan patub dan tunduk."

${ }^{10}$ M. Imadadun Rahmat dan Khamami Zada, "Agenda Politik Gerakan Islam Baru", dalam Jurnal Tashwirul Afkar, Edisi Khusus [Pergulatan Identitas Islam: Pergulatan Islamisme dan Islam Progresif], (Jakarta: Depag RI \& Lakpesdam NU), hlm. 39.

${ }^{11}$ Jamhari dan Jajang Jahroni, Gerakan Salafi Radikal ..., hlm.v. 
di pelbagai daerah ini diawali di Bekasi ${ }^{12}$, hingga berkembang di lebih dari 22 Kabupaten dan kota se Indonesia. ${ }^{13}$ Berbeda dengan Nanggroe Aceh Darusalam (NAD) yang melaksanakan Syariat Islam secara formal berdasarkan Undang-Undang Otonomi Khusus Aceh, maka implementasi di 22 Kabupaten/kota di atas rata-rata menerapkan Anti Maksiat, Kewajiban Berjilbab, ataupun Fasih baca Alqur'an melalui Peraturan Daerah. Daerahdaerah tersebut antara lain, Propinsi Banten, Propinsi Riau, Propinsi Gorontalo, Propinsi Sumatera Barat, Kota Makasar, Kota Ternate, kota Palembang, Kabupaten Banjar (Martapura), kabupaten Serang, kabupaten Tasikmalaya, kabupaten Sukabumi, kabupaten Cianjur, dan kabupaten Garut. ${ }^{14}$ Bahkan, empat kabupaten yang disebut terakhir, secara demonstratif, telah mendeklarasikan "pemberlakuan syari'at Islam" pada 1 Muharram tahun 2001. ${ }^{15}$

Di Kalimantan Selatan sendiri, fenomena formalisasi syari'at Islam ke dalam bentuk Peraturan daerah ini mulai terjadi secara khusus di kabupaten Banjar, Martapura. Pemerintah kabupaten Banjar dan DPRD-nya mulai tahun 2001 mengeluarkan Perda Puasa Ramadhan dan kemudian disusul Perda Khatam Qur'an dan Perda Pengelolaan Zakat tahun 2004, serta Perda Jum'at Khusu' No. 08 tahun 2005. ${ }^{16}$ Dengan terbitnya Perda-perda semacam itu, akhirnya kota Banjarmasin ${ }^{17}$ dan Amuntai, kab. Hulu Sungai Utara ${ }^{18}$ pun dan

${ }^{12}$ Penamaan Perda Bernuansa Syariat menjadi Perda Syariat atau Peraturan Daerah bernuansa Syariat Islam mulai digunakan pada saat sebuah interupsi di DPR RI dalam sebuah Sidang Paripurna oleh Sdr. Constant Ponggawa yang kemudian diikuti dengan sebuah surat permohonan kepada kepada Ketua DPR RI agar menyurati Presiden RI guna mencabut dan membatalkan Perda bernuansa syariat Islam tersebut. Surat tersebut dikeluarkan pada tanggal 17 Mei 2006 yang kemudian dalam pemberitaan Pers selanjutnya sering disingkat menjadi Perda Syariat saja. Lihat juga uraian Audy WMR Wuisang dalam http://audywuisang. blogspot.com/2007/05/perda-syariat-vs-nasionalisme-indonesia.html

${ }^{13}$ Majalah Tempo edisi 8, 14 Mei 2006.

${ }^{14}$ Nurrohman dan Marzuki Wahid, "Politik Formalisasi Syari'at Islam ..., hlm. 48.

15Ibid., hlm. 51.

${ }^{16}$ Lihat lebih jauh naskah-naskah berikut: (1) Perda Kab. Banjar No. 9 Tahun 2003 tentang Pengelolaan Zakat; (2) Perda Kab. Banjar No. 05 Tahun 2004 tentang perubahan atas Perda Kab. Banjar No. 10 Tahun 2001 tentang membuka restoran, warung, rombong dan yang sejenis serta makan, minum dan atau merokok di tempat umum pada bulan ramadhan; (3) Perda Kab. Banjar No. 04 Tahun 2004 tentang Khatam al-Qur'an bagi peserta didik pada pendidikan dasar dan menengah di kab. Banjar; (4) Perda kab. Banjar No. 08 Tahun 2005 tentang Jum'at Khusu'.

${ }^{17}$ Lihat lebih jauh lihat naskah-naskah berikut: Perda Kota Banjarmasin No. 13 Tahun 2003 tentang larangan kegiatan pada bulan Ramadhan. 
beberapa kabupaten di Kalimantan Selatan turut mengikuti gejala yang terjadi di pemerintahan kabupaten Banjar di atas.

Pola keberagamaan yang ditawarkan demikian ini tentu akan memanifestasikan adanya struktur teologi yang bersifat eksklusif yang penuh dengan muatan-muatan "klaim kebenaran" (truth claim). Bila saja pola keberagamaan yang demikian ini tetap dipertahankan, maka sudah bisa dipastikan bahwa pluralitas justru akan membawa agenda masalah "klasik" yang serius bagi kaum beragama itu sendiri. Kecenderungan bangkitnya kembali agama-agama dari proses marginalisasi dalam realitas modern, akan berdampak memperkuat akar konflik dan keterpisahan masyarakat agama yang satu dengan masyarakat agama yang lain.

Untuk itu satu titik sederhana yang ingin digarisbawahi di sini adalah upaya untuk memecahkan problem realitas pluralitas agama yang cukup pelik dalam era globalisasi sekarang ini. Pendekatan keberagamaan yang bersifat terbuka sangat dibutuhkan dalam era kehidupan msyarakat beragama yang bersifat pluralistik. Dengan pendekatan keberagamaan yang bernuansa demikian diharapkan bisa mengurangi - tanpa berpretensi lebih jauh ketegangan yang diakibatkan oleh klaim kebenaran (truth claim) dari masingmasing pemeluk agama.

Kebutuhan akan bentuk pendekatan keberagamaan yang demikian dikarenakan dalam era sekarang ini tidak lagi dapat didekati dan dipahami hanya lewat pendekatan teologis-normatif yang sangat terikat pada normanorma yang lebih menekankan petimbangan nilai (value judgement). ${ }^{19}$

${ }^{18}$ Lihat lebih jauh lihat naskah-naskah berikut: (1) Perda Kab. HSU No. 2 Tahun 1988 tentang pencegahan perbuatan pelacuran / tuna susila; (2) Perda Kab. HSU No. 32 Tahun 2003 tentang pencegahan dan pelarangan kegiatan yang menodai kesucian bulan Ramadhan.

${ }^{19} \mathrm{M}$. Amin Abdullah, "Tinjauan Antropolgis-Fenomenologis Keberagamaan Manusia: Pendekatan Filsafat Untuk Studi Agama-Agama”, dalam Abdurrahman, dkk (ed.), 70 Tabun H. A. Mukti Ali: Agama dan Masyarakat, (Yogyakarta: IAIN Sunan Kalijaga Press, 1993), hlm. 508 - 509. Lihat juga penjelasan yang lebih rinci dari M. Amin Abdullah, "bahwa pendekatan teologis sering kali membawa ke arah "ketersesatan" umat merupakan konsekuensi logis dari struktur fundamental bangunan teologi yang punya karakteristik, sebagai berikut: Pertama, lebih mengutamakan loyalitas yang lebih tinggi kepada kellompok sendiri. Kedua, adanya keterlibatan pribadi dan penghayatan yang begitu kental dan pekat kepada ajaran-ajaran yang diyakini kebenarannya. Ketiga, pengungkapan perasaaan dan pikiran dengan bahasa "aktor" (pelaku) dan bukannya bahasa pengamat (spectator). Menyatunya ketiga karakter ini dalam diri seseorang atau kelompok tertentu memberi andil yang cukup besar bagi terciptanya "enclaveenclave" komunitas yang cendrung eksklusif, emosional, dan kaku. Lebih dari itu, menyatunya sifat dasar teologi dalam diri seseorang atau kelompok akan menggoda para pemiliknya untuk 
Dalam konteks inilah, maka pemikiran Seyyed Hossein Nasr bisa menawarkan pendekatan keberagamaan yang direkonstruksinya melalui tradisi sufisme Islam yang sudah berabad-abad mentradisi dalam peradaban Islam. Tawaran ini memang terasa "usang", namun pemikiran Seyyed Hossein Nasr tetap bisa aktual karena bisa menjadi contoh dalam mengaktualisasikan peran sufisme Islam bagi masyarakat kontemporer.

\section{Perjumpaan Tasawuf dengan Filsafat Islam}

Dalam konteks tawaran Seyyed Hossein Nasr ini, alangkah baiknya kita melihat secara historis mata rantai intelektual tradisi pemikiran filsafat Islam yang bisa ditawarkan bagi penyelesaian problematika bangsa kita saat ini.

Sebagai orang yang dibesarkan di Iran, bagi Nasr, Iran tampak berbeda dengan kawasan Islam yang menganut mazhab Sunni, tradisi filsafat Islam terus berkembang sebagai tradisi yang hidup sesudah apa yang dikenal dengan abad tengah, dan terus bertahan sampai dewasa ini.

Dasar kuat yang menyebabkan terus hidupnya tradisi filosofis di dunia Islam Syi'ah Iran, diawali dari seseorang yang bernama Syah Isma’il yang berhasil mendirikan kerajaan Safawi yang mampu bertahan selama kurang lebih dari dua ratus tahun. Di bawah Kerajaan Safawi yang didirikan oleh Syah Isma'il (w. 1524) pada tahun $1499 \mathrm{M}$ inilah berbagai aliran pemikiran berkembang dalam matrik Syi'isme. Masa perkembangan ini mencapai kulminasinya dengan mazhab "mazhab Isfahan", yang dibangun oleh Mir Damad pada abad ke-10 H/16 M dan mencapai titik puncak pada Mulla Shadra. ${ }^{20}$

Mazhab ini merupakan sintesis, baik tradisi masysyaiyyah yang di Persia dihidupkan kembali oleh Nashir al-Din al-Tusi (w. 1273 M) maupun tradisi isyraqiyyah yang dikembangkan oleh Syam al-Din Syahrazuri dan Quthb al-Din al-Syirazi. Mereka juga bahkan mengenal baik pemikiran kalam dan irfan serta mengembangkan keduanya secara bervariasi. Di tangan Mulla Shadra, filsafat

mendahulukan "truthclaim" dari pada dialog yang jujur dan argumentatif". Lihat M. Amin Abdullah, Studi Agama: Pendekatan Agama, Makalah dalam Peringatan 100 Tahun Perlemen Agama-Agama se-Dunia dan Kongres Nasional I Agama-Agama di Indonesia (Yogyakarta: 11 - 12 Oktober 1993), hlm. 17.

${ }^{20}$ Seyyed Hossein Nasr, "Pengantar", dalam Mehdi Ha'iri Yazdi, Ilmu Hudhuri; PrinsipPrinsip Epistemologi dalam Islam, diterjemahkan oleh Ahsin Muhammad, (Bandung: Mizan, 1994), hlm. 9. 
ini dikembangkan menjadi suatu tradisi filsafat teosofi transenden (al-hikmah almuta'aliyyah). ${ }^{21}$

Meskipun terjadi pasang surut pada masa akhir periode Safawi dan pengrusakan sebagian besar kota Isfahan akibat serbuan bangsa Afgan pada abad ke-12 H/18 M, namun obor filsafat Islam yang menyala kembali di tangan Sadr al-Din al-Syirazi - atau yang lebih dikenal dengan sebutan Mulla Shadra (w. 1641 M) - terus berlanjut hingga masa Dinasti Qajar. Pada masa Dinasti ini sekali lagi Isfahan di bawah Mullah 'Ali Nuri (w. 1832 M) menjadi pusat besar filsafat. ${ }^{22}$ Sementara Teheran juga muncul sebagai pusat kegiatan filsafat sejak abad ke-13 H/19 M hingga masa pemerintahan Pahlevi. Kebanyakan guru-guru yang terkenal pada periode ini, antara lain Mirza Mahdi Ashtiyani (w. 1337 H/ 1953 M), Seyyed Muhammad Kazim 'Assar (w. 1394 H/ 1975 M), dan Seyyed Abu’l Hasan Qazwini (w. 1394 H/ 1975 M) mengajar di Teheran. ${ }^{23}$

Setelah Perang Dunia ke-2, Qum juga menjadi pusat pengkajian filsafat yang penting. Di antara tokoh penting di sini, antara lain 'Allamah Sayyid Muhammad Husayn Tabataba'I (w. 1402 H/ 1981 M). Dari tokoh ini lahirlah Murthada Muthahari, Sayyid Jalal al-Din Asytiyani, dan Mahdi Ha'iri Yazdi, yang memperoleh tradisi hidup sampai dewasa ini. ${ }^{24}$

Begitu lekatnya tradisi filsafat Islam ini di hati kaum muslimin Syi'ah di Iran, hingga Ayatullah Khomaeni - Pimpinan Spiritual Iran yang wafat tahun 1989 -- menulis surat kepada Presiden Uni Soviet Michael Gorbachev yang berisi anjuran agar pemimpin Soviet tersebut "menelaah" karya besar Shadr Muta'allihin tentang al-bikmah al-muta'aliyyah.

Dari sudut ini, filsafat Islam tidak pernah mati sebagaimana yang dituduhkan, tetapi karakternya secara radikal berubah akibat pengaruh sufisme. Dari sudut ini pula, bisa dibayangkan bagaimana gelora tradisi intelektual awal yang mempengaruhi dan menjadi latar belakang pemikiran Seyyed Hossein Nasr.

Pemikiran Nasr sangat kompleks dan multi dimensi. Dalam konteks ini, Nasr dalam kerangka intelektualitasnya berusaha mengembangkan suatu perennial philosophy atau hikmah laduniyah. Oleh karenanya, apa yang disebut

\footnotetext{
${ }^{21}$ Seyyed Hossein Nasr, "Theology, Philosophy, and Spirituality", dalam Seyyed Hossein Nasr, Islamic Spiritualit: Manifestation, (New York: Crossroad, 1991), hlm. 432-437.

${ }^{22}$ Seyyed Hossein Nasr, "Pengantar", ..., hlm. 9.

${ }^{23}$ Seyyed Hossein Nasr, "Theology, Philosophy, ..., hlm. 438.

${ }^{24}$ Ibid.
} 
dengan filsafat adalah suatu bagian doktrinal dari jalan spiritual yang menyeluruh, yang disertai dengan metode realisasi yang tidak dapat dipisahkan dari wahyu Tuhan atau tradisi yang membuka jalan spiritual (sufisme). ${ }^{25}$

Masuknya dimensi sufisme dalam filsafat dimaksudkan untuk memberikan dimensi metafisika dalam filsafat. Penyatuan filsafat dengan sufisme $^{26}$ dijelaskan Nasr dengan mencatat adanya lima bentuk hubungan antara sufisme dan filsafat. ${ }^{27}$ Pertama, kritik dari kelompok sufi atas filsafat yang hanya memperhatikan aspek rasional dari filsafat, dan setiap kali berbicara tentang intelek ('aql) kaum sufi tidak mengartikan intelek dalam pengertian mutlaknya namun mengacu pada aspek rasional intelek atau akal (reason). Kedua, munculnya bentuk khusus sufisme yang terjalin erat dengan filsafat, yang disebut sebagai filsafat atau teosofi (bikmah) dalam bentuk yang paling luas. Ketiga, munculnya tokoh-tokoh sufi yang sekaligus juga filsuf, diantaranya Afdhaluddin Kasyani, Quthbuddin Syirazi, Ibnu Turkah al-Isfahani, dan Mir Abul Qasim Findiriski. Keempat, munculnya para filsuf yang mempelajari, atau dalam bebarapa hal, mempraktekkan sufisme, diantaranya pada Ibnu Sina, alFarabi, dan Syeikh Khawaja Nasiruddin al-Thusi. Kelima, munculnya kelompok filsuf yang berorientasi dan tertarik pada sufisme, dimana mereka tidak hanya mempertahankan dan menyenangi sufisme tetapi juga menulis risalah yang tidak memisahkan antara filsafat dan sufisme sebagaimana yang dirintis jalannya oleh Syeikh al-Tsyraqi. Dengan menunjukkan lima bentuk hubungan

${ }^{25}$ Seyyed Hossein Nasr, Islam dan Nestapa ..., hlm. 48.

26 Tidak semua pemikir setuju dengan Nasr. Filsuf Mesir, Ahmad Fuad al-Ahwani, berpendapat bahwa berfilsafat harus dilakukan dengan akal pikiran dan melalui jalan pembuktian menurut logika. Hal ini karena tasawuf memandang sesuatu melalui jalan melatih kekuatan rohani (mujahadab), penglihatan batin (musyabadah) dan mengutamakan tanggap rasa (dzanq). Objek studi filsafat adalah mengenai hakikat segala sesuatu, baik mengenai alam, ilmu pasti, maupun metafisika (yang di dalamnya antara lain membahas tentang Tuhan. Filsafat juga membahas tentang manusia sekitar kodrat dan tingkah lakuknya dari sudut moral dan politik sebagai filsafat amaliyah. Sementara tasawuf adalah soal cara mengenal Allah melalui jalan mujahadah, musyahadah, dan dzanq, sehingga terbuka pancaran Tuhan (futubat rabbaniyyah). Lihat Ahmad Fuad al-ahwani, Filsafat Islam, disunting oleh Sutardji Calzoum Bachri, Jakarta: Pustaka Firdaus, 1988), hlm. 18-19. Orang seperti al-Ahwani cenderung membedakan secara metodis antara jalan filsafat dengan jalan tasawuf. Pembedaan ini sangat penting supaya tidak mencampurbaurkan antara filsafat sebagai suatu jalan menghayati kebenaran tersebut dengan jalan melalui pengalaman intuitif.

${ }^{27}$ Seyyed Hossein Nasr, "Hubungan antara Filsafat dan Tasawuf: Kasus Kultur Persia”, diterjemahkan oleh Ihsan Ali-Fauzi, dalam Jurnal al-Hikmah, No. 5, Maret-Juni 1992, hlm. 62-92. 
tersebut, seolah-olah Nasr ingin menyatakan bahwa penyatuan tersebut, selain punya pijakan historis juga menjadi sesuatu yang mendasar bagi pengembangan filsafat Islam modern.

Oleh karena itu, apa yang menjadi kecenderungan dalam corak pemikiran Nasr ini merupakan representasi dari suatu kecenderungan dalam tradisi filsafat Islam yang bergaya "Neo-Platonik" (Isyaraqiyyah), ${ }^{28}$ khususnya Mazhab Mulla Shadra. ${ }^{29}$ Hal ini bisa dilihat pada kutipan sebagai berikut:

\footnotetext{
${ }^{28}$ Menurut Muthahhari, para filsuf muslim dapat dibagi ke dalam dua kelompok, yakni penganut Illuminasionisme dan Peripatetisme. Kaum illuminasionis biasanya dipandang sebagai pengikut Plato, sedangkan kaum peripatetik dipandang sebagai pengikut Aristoteles. Namun begitu, tidak jelas mengapa Plato bisa dianggap sebagai seorang illuminasionisme. Penokohan Plato atas tradisi illuminasionisme lebih didapatkan pada karya-karya Suhrawardi, khususnya dalam Hikmah al-Isyaraq (Kebijaksanaan Pencerahan) - yang tentunya tak seorang filsuf muslim, baik al-Farabi dan Ibnu Sina atau para sejarawan filsafat seperti Syahrastani, yang berbicara tentang Plato sebagai seorang pemikir yang mendukung kebijaksanaan illuminasionis. Apakah Plato seorang illuminasionis dalam metodenya atau tidak, terdapat gagasan penting di antara kepercayaannya yang menjadi ciri filsafatnya yang oleh Aristoteles ditolaknya. Gagasan Plato itu antara lain: (1) teori tentang ide, yang menyatakan bahwa segala sesuatu yang kita saksikan di dunia ini, baik substansi maupun aksiden, mempunyai asal-usul dan realitas di dunia lain. Wujud individual dunia ini tampil sebagai bayangan atau refleksi dari realitas-realitas dunia yang lain. Plato menyebut realitas-realitas ini sebagai ide-ide. Di masa-masa Islam, kata Yunani bagi Ide diterjemahkan sebagai mitsal (keserupaan), dan realitas-realitas ini secara kolektif disebut sebagai mutsul-I Aflathuni (ide-ide Platonik). Filsuf-filsuf muslim yang berpegang teguh pada gagasan ini adalah Suhrawardi, Mir Damad dan Mulla Shadra dengan formulasi yang berbeda oleh filsuf yang disebut terakhir; (2) teori tentang jiwa, yang menyatakan jiwa diciptakan walau adanya mendahului tubuh yang berasal dari dunia yang sama, yakni dunia ide ('alam-I mutsul); (3) teori tentang pengetahuan, yang menyatakan pengetahuan menjelma lewat pengingatan kembali (recolection) bukan lewat belajar. Lihat Murthada Muthahhari, Tema-Tema Filsafat Islam, diterjemahkan oleh A. Rifa'I Hasan, (Bandung: Yayasan Muthahhari, 1993), hlm. 29-40.

${ }^{29}$ C. A. Qadir, Filsafat dan Ilmu Pengetahuan dalam Islam, diterjemahkan oleh Hasan Basri, (Jakarta: YOI, 1989), hlm. 155. Menurut Muthahhari, dalam tradisi filsafat Islam ada empat mazhab pemikiran yang mewarnai, yakni illuminasionisme, peripatetisme, gnosis (Irfan) dan kalam (teologi skolastik). Empat macam arus pemikiran ini terus mengalir di dunia Islam hingga mereka mencapai titik temu yang disebut sebagai "Kearifan Puncak" (bikmah almuta'aliyyah). Kearifan puncak sebagai sebuah ilmu dirintis oleh Shadr al-Muta'allihin Syirazi (Mulla Shadra) (w. 1050 H/ 1640 M). Istilah "Kearifan Puncak" pernah digunakan oleh Ibnu Sina dalam Isyarat, tetapi filsafat Ibnu Sina tidak pernah disebut dengan nama ini. Mulla Shadra secara formal menamakan filsafatnya dengan "Kearifan Puncak". Ajarannya menyerupai ajaran Suhrawardi, yakni menggabungkan demonstrasi dengan penampakan mistik dan penyaksian langsung, tetapi berbeda dalam prinsip-prinsip dan kesimpulan. Dalam mazhab Mulla Shadra, banyak titik perselisihan antara mazhab peripatetik dan illuminasionisme, antara filsafat dan
} 
Mulla Shadra membuat satu sintesis luas, yang mendominasi kehidupan intelektual Persia dan sebagian India Muslim sepanjang beberapa abad lalu. Ia bersama Suhrawardi memberikan suatu wawasan mengenai alam yang memuat berbagai unsur sains alam yang telah dikembangkan lebih dahulu dan yang merupakan matriks sains intelektual dan filosofis, khususnya di negara-negara Timur Islam. ${ }^{30}$

Ketertarikan Nasr terhadap corak pemikiran tokoh ini disebabkan pada Mulla Shadra bisa ditemukan suatu harmoni yang sempurna antara kutubkutub rasionalisme dan perspektif yang bersifat mistik. Melalui pengawinan intelek pada wahyu, Shadra mencapai suatu coincidentia oppositorum, mencakup kekuatan logika dan ketersingkapan spiritual secara langsung. Seperti Hikmah al-Isyraq, yang dimulai dengan logika dan berakhir dengan ekstase secara mistik. Mulla Shadra menggelorakan sebuah pola pemikiran dimana logika dibenamkan ke dalam lautan cahaya gnosis. Shadra menyebut sintesis ini - yang dianggap menjadi dasar khususnya tentang tiga jalan besar menuju kebenaran bagi manusia, yakni wahyu (wahyu atau shar), inteleksi ('aql) dan keterbukaan secara mistik (kasf) -- al-bikmah al-muta'alliyyah atau teosofi transenden. ${ }^{31}$

Tradisi ini menempatkan kemungkinan akhir manusia terdiri dari ekstasis, yaitu perjumpaan manusia dengan Tuhannya yang melampaui indera dalam keadaan "Tuhan turun atas roh manusia", sehingga menimbulkan suasana kesatuan cinta yang mesra dan tak terperikan antara manusia dan Tuhan.

\section{Berkaca Dari Pemikiran Seyyed Hossein Nasr}

Memasuki pemikiran Nasr tentang pluralitas dan multikulturalitas agama, paling tidak ada tiga konsep world-view sufisme yang ditawarkan Nasr dalam memahami realitas agama, yaitu (1) Tatanan Hirakhir Realitas; (2) Yang Absolut Secara Relatif; (3) dan Akal, Intelek, dan Intuisi.

\section{Tatanan Hirarkhi Realitas}

Konsep kunci Nasr dalam memahami agama terletak dalam kerangka konsep tatanan realitas kosmos yang hirarkhis. Tatanan ini memperlihatkan

Irfan, atau antara filsafat dan kalam, menemukan penyelesaiannya. Lihat Murthada Muthahhari, Tema-tema Penting ..., hlm. 41-50.

${ }^{30}$ Seyyed Hossein Nasr, Science and Civilization in Islam, (New York: New American Library, 1970), hlm. 336.

${ }^{31}$ Seyyed Hossein Nasr" Theology, Philosophy, and the Spirituality", dalam Seyyed Hossein Nasr (ed), Islamic Spirituality: Manifestation, (New York: Crossroad, 1991), hlm. 434. 
adanya kaitan seluruh eksistensi yang ada di alam semesta ini dengan Yang Absolut. Dengan demikian, di balik kenyataan ini harus selalu disadari adanya Yang Tak Terbatas (infinite). Prinsip ini tidak lain merupakan prinsip metafisika yang menekankan kesatuan sekaligus gradasi kenyataan. Artinya, prinsip realitas adalah satu namun secara kosmologis dunia nyata merupakan pengejawantahan majemuk dari "Kehadiran Ilahi". ${ }^{22}$

Menurut Nasr, realitas tidak hilang oleh dunia psikofisik dimana manusia biasa berfungsi, atau kesadaran tak terbatas pada tingkat kesadaran biasa (sehari-hari) dari kemanusiaan sekarang. Realitas Tertinggi melampaui semua ketentuan dan batasan. Ia Absolut dan Tak Terbatas. Dari-Nya kebaikan melimpah seperti cahaya dari matahari. Apakah prinsip itu dilihat sebagai kepenuhan atau kekosongan tergantung pada titik pangkal penafsiran metafisika tertentu dalam masalah yang dibicarakan. Seperti yang dikemukakan oleh guru-guru Timur, Maya adalah Atman atau Samsara adalah Nirvana, maka orang dapat mengatakan bahwa pernyataan itu hanya mungkin jika seseorang pertama-tama mengetahui bahwa maya adalah maya atau samsara adalah samsara. Prinsip itu dapat pula dilihat sebagai "Aku" tertinggi, yang lebih memandang kutub subjektif ketimbang kutub objektif dimana kesadaran biasa kemudian lebih dipahami sebagai bungkus luar dari Diri Tertinggi daripada turunannya ke kenyataan yang lebih rendah dalam hirarkhi universal. Namun demikian, pengertian yang lain apakah dipahami sebagai Yang Transendental atau Yang Immanen, prinsip itu memunculkan suatu universum hirarkhis yang memiliki banyak tingkat eksistensi atau keadaan kesadaran dari Prinsip Tertinggi ke manusia dan lingkungan bumi. ${ }^{33}$

Dalam khazanah pemikiran Islam tradisional, dikenal lima tingkatan wujud atau "kehadiran", yakni: Dunia Hakikat Ilahi (Hubut); dunia Nama dan Sifat Ilahi atau Kecerdasan Universal, yang juga dikenal dengan Wujud Murni (labut); dunia yang dipahami atau dunia zat malaikat (jabarut); dunia psikis dan manifestasi "halus" (malakut); akhirnya daerah dunia fana atau fisik yang dikuasai manusia (nasut). Kelima tingkatan wujud tersebut kadang ditambahkan tingkatan wujud keenam, yaitu tingkatan manusia universal (al-insan al-kamil) yang mengandung semua tingkatan wujud tersebut. ${ }^{34}$ Tatanan hirakhis realitas tersebut lazim digambarkan dalam terminologi sufi ke dalam tiga realitas

\footnotetext{
${ }^{32}$ Seyyed Hossein Nasr, Science and Civilization ..., hlm. 93.

${ }^{33}$ Seyyed Hossein Nasr, "Philosophia Perennis", ..., hlm, 184-185.

${ }^{34}$ Seyyed Hossein Nasr, Science and Civilization ..., hlm. 93.
} 
fundamental, yang secara berurutan disebut alam nasut, malakut, dan jabarut. ${ }^{35}$ Dengan mendasarkan pada al-Qu'an, kaum sufi memformulasikan doktrin "lima keberadaan Ilahiah" (al-hadharat al-Ilabiyat al-khams) untuk menggambarkan hirarkhi seluruh realitas. ${ }^{36}$

Ketiga realitas di atas - material, halus dan spiritual - dalam urutan itu, juga merupakan tiga "tingkatan wujud" yang pertama dalam urutan menaik. Tingkat realitas atau "wujud" selanjutnya yang lebih tinggi dalam hirarkhi ini adalah alam Sifat-Sifat Ilahiah (asma' sifatiyyah). Wujud keempat, yang disebut lahut dapat dipersamakan dengan Prinsip Kreatif atau Wujud, yakni prinsip ontologis dari keseluruhan kosmis. "Wujud" selanjutnya atau yang tertinggi adalah Essensi Ilahi (al-dzat). "Derajat" yang diistilahkan sebagai babut ini adalah Diri Tertinggi dan Tak Terbatas, Wujud Tak Tergapai yang merupakan Prinsip "Tak Dapat Disifati” dan "Tak Dapat Ditentukan". Tingkat-tingkat eksistensi ini membangun rantai eksistensi yang tak terpisahkan, yang dalam terminologi sufi disebut "dunia bentuk yang bergantung" (shuwar al$m u^{\prime}$ allaqah). ${ }^{38}$

Setiap tingkat eksistensi kosmik memiliki eksistensi yang bersesuaian dalam diri manusia. Struktur tripatrit kosmos tradisional bersesuaian dengan struktur tripatrit mikrokosmos manusia tradisional yang terdiri dari tubuh (corpus), jiwa (anima, psyche), dan roh (spiritus). Dalam terminologi Islam, unsurunsur mikrokosmis yang esensial ini secara berturut-turut disebut jism, nafs, dan aql..$^{39}$

Menurut Nasr, penolakan terhadap realitas hirarkhis di atas oleh banyak sarjana modern telah mempengaruhi pandangan-dunia dan metodologi mereka dalam studi agama dan agama-agama. Sementara bagi kaum tradisional, penerimaan terhadap pandangan metafisik tersebut telah membentuk suatu ciri esensial dalam studi agama dan agama-agama dalam aspek-aspeknya yang berbeda. $^{40}$

${ }^{35}$ Seyyed Hossein Nasr, Spiritualitas dan Seni Islam, diterjemahkan oleh Sutejo, (Bandung: Mizan, 1993), hlm. 76.

${ }^{36}$ Ibid., hlm. 197-198.

${ }^{37}$ Osman Bakar, "Masalah Metodologi dalam Sains Islam", dalam Taubid \& Sains; Esai-Esai tentang Sejarah dan Filsafat Sains Islam, diterjemahkan oleh Yuliani Liputo, (Bandung: Pustaka Hidayah, 1994), hlm. 31-32.

${ }^{38}$ Seyyed Hossein Nasr, Spiritualitas ..., hlm. 197.

${ }^{39} \mathrm{Ibid}$, hlm. 34.

${ }^{40}$ Seyyed Hossein Nasr, "Philosophia Perennis", hlm. 187. 
Pentingnya pengandaian realitas dalam wilayah agama dan agamaagama, menurut Nasr, dikarenakan seperti dunia fenomenal yang mensyaratkan adanya dunia nomenal, aspek formal agama juga sesungguhnya mensyaratkan yang essensial dan supraformal. Di samping itu, ada tingkat-tingkat yang lebih jauh dalam yang essoterik dan eksoterik, sehingga dalam setiap agama yang utuh terdapat suatu hirarkhi atau tingkatan-tingkatan dari yang paling luar sampai pusat yang paling dalam, dari yang paling rendah sampai Yang Tertinggi. ${ }^{41}$

Oleh karena itu, bentuk-bentuk lahiriah dari suatu agama dapat dilihat sebagai aksiden yang keluar dari dan kembali ke substansi yang tetap independen dari semua aksidennya. ${ }^{42}$ Hubungan dialektis ini menggambarkan bahwa essoterisme merupakan sumber Asal bagi eksistensi agama, sedangkan eksoterisme merupakan sarana bagi pencapaian manusia kepada sumber Asal tersebut.

Pemahaman yang demikian inilah yang memberi kesimpulan pada Nasr untuk melihat semua agama adalah sekaligus Sang Agama dan sebuah agama. Sang Agama, karena di dalamnya terkandung kebenaran dan cara untuk mencapainya, sedangkan sebuah agama karena penekanannya terhadap aspek tertentu dari kebenaran yang disesuaikan dengan kebutuhan spiritual dan psikologis manusia, kepada siapa agama diturunkan. ${ }^{43}$

Dalam konteks ini, lalu agama dipahami sebagai media menerjemahkan berbagai kebenaran metafisik atau kebenaran universal mengenai Yang Mutlak ke dalam bahasa dogmatis. Konsepsi dogmatis, pada dasarnya, dapat diibaratkan dengan suatu pandangan eksklusif tentang salah satu dari Yang Mutlak. Namun demikian, arti penting dari realitas eksoterisme bukan berarti tidak penting. Aspek eksoterisme dan essoterisme mempunyai nilai yang saling melengkapi.

\section{Yang Absolut Secara Relatif}

Adanya tatanan hirarkhi dalam realitas agama yang punya konsekuensi pada hubungan aspek eksoterisme dan aspek essoterisme dalam realitas agama, tentunya, membawa akibat logis pada pola pemahaman tentang kehadiran kebenaran yang dibawa agama. Sebagaimana Schuon yang mengkonsepsi kehadiran kebenaran agama-agama sebagai "Yang Absolut secara relatif"

${ }^{41}$ Ibid., hlm. 187.

42Seyyed Hossein Nasr, "Philosophia Perennis", ..., hlm. 190.

${ }^{43}$ Seyyed Hossein Nasr, Islam dalam Cita dan Fakta, diterjemahkan oleh Abdurrahman Wahid dan Hasyim Wahid, (Jakarta: LEPPENAS, 1981), hlm. 1. 
(relatively absolute), yakni "yang nampaknya kontradiktif tapi secara metafisik bermakna", begitu juga Nasr memahaminya sebagai konsekuensi-logis dari pemahaman tentang realitas agama tadi. Uraian di atas bisa dianalogikan dengan sistem matahari kita. Matahari kita adalah matahari ketika dilihat dalam perspektif ruang galaktik, padahal ia hanya satu di antara sekian banyak matahari. ${ }^{44}$

Dalam setiap alam keagamaan, ada logos, Nabi, Kitab Suci, inkarnasi atau sejumlah penjelmaan langsung dari Keilahian atau pesan dari Firman-Nya dan suatu pesan tertentu - yang sesuai dengan "wadah manusia"-Nya, apakah itu bahasa Arab bagi al-Qur'an atau tubuh Kristus bagi agama Kristen bersifat "absolut bagi alam keagamaan yang dijelmakan wahyu. Namun demikian, penjelmaan-penjelmaan tersebut bersifat "absolut secara relatif".

Dalam setiap alam keagamaan, hukum-hukum yang ditampakkan, simbol-simbol yang disakralkan, doktrin-doktrin yang dikeramatkan oleh otoritas-otoritas tradisional, do'a-do'a yang menghidupkan agama, semuanya bersifat absolut dalam dunia keagamaan dan bersifat tidak absolut dalam artian dirinya sendiri. Pada jantung setiap agama ditemukan ungkapan Tuhan yang mengatakan "Aku", tetapi banyak gema kosmik dan bahkan metakosmik dari Firman yang satu sekaligus banyak, dan diidentikkan setiap agama dengan para pendirinya. ${ }^{46}$

Pada tataran ulasan inilah, Nasr meletakkan dasar dalam melihat realitas agama pada Asal Ilahi Yang Absolut tanpa menolak menifestasi-manifestasiNya atau kemungkinan-kemungkinan lainnya yang mengalami perubahan karena perubahan waktu. Hal ini dikarenakan "setiap agama mempunyai kemungkinan-kemungkinan prinsipil tertentu yang terkandung dalam pola dasar (archetype) langit-Nya. Kemungkinan-kemungkinan ini terrealisasi atau menjadi terhampar dalam periode historis dan humanitas yang menjadi wadahwadah manusiawi dan temporal dari agama. ${ }^{47}$

Penelusuran Nasr atas realitas hakiki agama di atas menjelaskan suatu tatanan realitas agama yang jauh melampaui fenomena agama itu sendiri, yakni fenomena lembaga manusiawi dalam mengekspresikan sesuatu yang tidak terhingga dalam pengalaman manusiawinya. Dengan demikian, agama dalam pemahaman Nasr di atas mencerminkan realitas kesemestaan hubungan

\footnotetext{
${ }^{44}$ Seyyed Hossein Nasr, "Philosophia Perennis" ..., hlm. 191.

${ }^{45}$ Ibid., hlm. 192.

${ }^{46}$ Ibid., hlm. 192.

${ }^{47}$ Ibid., hlm. 192.
} 
manusia dengan Asal Ilahiah yang universal. Pencerminan realitas agama yang begitu universal demikian akan membawa pemahaman pada proses pencarian yang tiada henti. Oleh karenanya, jika realitas ini dikaitkan dengan pendekatan terhadap agama, ia akan membawa akibat pada prosedur unik dalam mencapai tatanan hakikat realitas agama itu sendiri. Artinya, memahami realitas agama jauh melampaui realitas manusia itu sendiri. Karenanya, perspektif yang dibutuhkan dalam memahami realitas agama juga merupakan suatu perspektif yang mempunyai perspektif prosedur tentang piranti-piranti yang mampu mengaitkan realitas pada tatanan historis hingga metahistoris (tatanan spiritualitas).

\section{Akal, Intelek, dan Intuisi}

Menurut Nasr, istilah tunggal al-'aql dipakai untuk menyatakan nalar (reason) maupun intelek. Akal yang diterjemahkan sebagai "nalar" adalah bagian dari akal pada tingkat yang rendah, yang dimiliki oleh semua manusia normal. Tepatnya, ia adalah akal diskursif, yang bekerja mengikuti langkah-langkah logis dengan merujuk pada pengalaman dunia material. ${ }^{48}$ Dengan demikian, sejak awal ia sudah membatasi wilayah atau jangkauan konsep yang ingin dijelaskan. Sedangkan akal yang diterjemahkan sebagai "intelek" adalah bagian dari akal pada tingkat yang paling tinggi yang dapat memperoleh pengetahuan secara langsung dan segera. Secara langsung di sini dimaksudkan merujuk pada cara memperoleh pengetahuan yang tidak melewati fakultas rasional dan biasanya disebut sebagai penyingkapan $(\text { kasyf) })^{49}$

Menurut Nasr, fungsi intelek hanya terlihat pada cahaya kemampuannya membentangkan kebenaran-kebenaran wahyu. Wahyu atau risalah dijadikan alat utuk mencapai kebenaran, dan wahyupun berfungsi menerangi intelek serta memungkinkannya untuk berfungsi sebagaimana mestinya. Perkawinan antara wahyu dan intelek ini sesungguhnya telah memungkinkan pikiran untuk berperan serta dalam kebenaran melalui tindakan intuisi. ${ }^{50}$ Hanya dengan berserah diri kepada wahyu inilah, intelek tidak saja mampu menelaah atau menganalisis tetapi juga mampu membuat sintesis dan unifikasi. Dalam fungsi unifikasi ini, intelek terselamatkan dan menyelamatkan

\footnotetext{
${ }^{48}$ Seyyed Hossein Nasr, "Hubungan antara Intelek dan Intuisi dari Perspektif Islam", dalam Salem Azzam (ed), Islam dalam Masyarakat Kontemporer, diterjemahkan oleh Hamid L. A. Basalamah, (Bandung: Gema Risalah, 1988), hlm. 54-55.

${ }^{49}$ Seyyed Hossein Nasr, Islam dan Nestapa ..., hlm. 24. Lihat juga, Seyyed Hossein Nasr, Tentang Istilah 'Aql, Intelek, dan Akal, dalam Jurnal al-Hikmah, No. 5, Ramadhan Dzulqa’idah 1412 / Maret-Juni 1992, hlm. 54.

${ }^{50}$ Seyyed Hossein Nasr, "Hubungan Antara Intelek ...”, hlm. 56.
} 
jiwa dari berlimpahnya kemajemukan dan keterpisahan. Dalam cahaya wahyu, intelek berfungsi tidak hanya sebagai nalar melain juga sebagai intuisi intelektual yang memungkinkan umat manusia menembus makna agama. ${ }^{51}$

Yang dimaksud dengan intuisi di sini bukan semata-mata suatu kekuatan inderawi atau ragawi yang meletup-letup dalam kegelapan melainkan suatu kekuatan yang menerangi serta mengubah batas-batas penalaran dan keberadaan manusia. ${ }^{52}$ Mengenai intuisi ini, Nasr menyamakannya dengan istilah hads, firasah, dhawq, mukasyafah, basyirah, nazar, dan badibah. Istilah ini menyatakan secara tersirat suatu partisipasi dalam ilmu, yang tidak hanya bersifat rasional tetapi juga tidak menyalahi intelektual. Istilah ini berkaitan dengan wawasan dan partisipasi langsung dalam ilmu kebenaran, yang berlawanan dengan ilmu tak langsung yang mendasari seluruh penalaran. Pertentangan inipun ditekankan dalam pemakaian istilah al-ilm al-buduri (ilmu pemberian) berlawanan dengan al-ílm al-busuli (ilmu pencapaian). Namun demikian, kedua istilah ini tidak menunjukkan perbedaan antara intuisi sebagai bentuk ilmu yang didasarkan pada pengalaman dan penalaran langsung sebagai ilmu yang didasarkan pada konsep mental, tetapi berfungsi sebagai pelengkapnya dalam arti paling mendasar. Islam tidak mengenal pemisahan antara intelek dan intuisi tetapi malah menciptakan suatu hirarkhi ilmu dan metode-metode pencapaian ilmu yang menyelaraskan tingkat-tingkat intelek maupun intuisi dalam suatu tatanan yang mengarahkan sarana-sarana yang tersedia untuk diketahui oleh manusia. ${ }^{53}$

Dalam konteks ini, Nasr lalu menegaskan sebagai berikut:

... terdapat suatu hirakhi pengetahuan dari yang inderawi, melalui yang khayal dan yang rasional, sampai pada yang intelektual yang juga intuitif dan dikenal dengan nama hati atau batin. Tetapi seperti halnya fakultas pengetahuan yang intelektual tidak dipertentangkan dengan yang sensual (inderawi), yang intelektual dan intuitif itupun tidak dipertentangkan dengan yang rasional. Malah, justru akal merupakan pantulan dari hati, yakni sebagai pusat mikrokosmis. Doktrin atau ajaran Islam tentang Ketuhanan (al-tawbid) telah mampu merangkum semua model pengetahun ke dalam suatu peringkatan hirakhi yang saling melengkapi dan serasi menuju suatu bentuk pengetahuan

\footnotetext{
${ }^{51}$ Seyyed Hossein Nasr, Knowledge and the Sacred, (Edinburgh: Edinburgh Univ. Press, 1981), hlm. 149.

${ }^{52}$ Seyyed Hossein Nasr, "Hubungan antara Intelek ...”, hlm. 61.

${ }^{53} \mathrm{Ibid}$., hlm. 55-56.
} 
terluhur, yakni ma'rifah dari hati yang suci yang pada akhirnya tidak lain merupakan pengetahuan yang esa dan mengesakan tentang Yang Maha Esa serta pelaksanaan paling mendasar dari Keesaan Tuhan (al-tawbid). ${ }^{54}$

Walaupun tidak begitu tegas merinci kaedah-kaedah fungsional antara 'aql sebagai nalar maupun intelek dan intuisi dalam kerangka epistemologisnya, Nasr kelihatan sangat bersemangat untuk mengaktualisasikan tradisi pemikiran Islam bergaya isyraqiyyah, dimana hirarkhi pengetahuan amat memberi warna dalam wacana epistemologisnya.

\section{Kesatuan Transenden Agama-Agama}

Berpijak dari tiga konsep world view sufisme di atas, Nasr mengaitkan tradisi Timur di atas dengan filsafat perennial, dimana pengetahuan selalu terkait dengan aspek-aspek sakral (suci) dan spiritual, sebagai pendekatan terhadap fenomena pluralisme agama. Walaupun Nasr tidak begitu orisinil dalam menggagas pendekatan filsafat perennial sebagai pendekatan alternatif dalam memahami agama, namun cara Nasr merumuskan filsafat perennial dari kerangka sufisme Islam, sebagaimana yang terangkum dalam Knowledge and the Sacred ${ }^{55}$ menjadikan pemikirannya menjadi unik dan khas.

Dalam konteks buku tersebut, Nasr secara gamblang mengaitkan filsafat perennial dengan tradisi Timur, dimana pengetahuan selalu terkait dengan aspek-aspek sakral (suci) dan spiritual. Proses mengetahui dalam tradisi Timur, dengan demikian, bukanlah proses yang semata-mata tertumpu pada

${ }^{54} \mathrm{Ibid}$., hlm. 66.

${ }^{55}$ Seyyed Hossein Nasr, Knowledge and the Sacred, (Edinburgh: Edinburgh Univ. Press, 1980). Ada dua alasan penting untuk menjadikan buku Knowledge ini sebagai rujukan utama. Pertama, Knowledge mencerminkan kekayaan Nasr di bidang tradisi, baik yang menyangkut khazanah sufistik, filosofis, teologis maupun saintifik. Kedua, Knowledge adalah karya Nasr yang menunjukkan keterlibatannya yang intens dalam wacana perennialisme, yang menempatkan Nasr bersama-sama dengan Frithjof Schuon, Huston Smith, Martin Ling, dan sarjana-sarjana lain yang sealiran. Di samping itu, nampak sekali buku tersebut ditulis Nasr dengan sangat sangat ambisius. Seperti yang dituturkannya sendiri dalam kata pengantar buku tersebut, penulisan buku tersebut berasal dari kesempatan yang diterima Nasr untuk menyampaikan pidato dalam Gifford Lectures, sebuah forum yang sangat bergengsi bagi kalangan teolog, filsuf, dan saintis Amerika dan Eropa sejak tahun 1889. Pidatonya sekitar tahun 1985 menjadikan dirinya sarjana muslim pertama, bahkan sarjana Timur pertama yang tampil dalam forum itu sejak pertama kalinya digelar hampir satu abad yang lalu di Universitas Edinburgh. Nasr memanfaatkan kesempatan itu untuk menyajikan "beberapa aspek kebenaran yang terletak di jantung tradisi-tradisi Timur bahkan jantung semua tradisi, baik di Barat dan Timur”. 
pencernaan otak melalui prosedur dan kerja kolektif panca-indera yang tersedia. Sebagai konsekuensi lebih lanjut, kualitas pengetahuan dalam tradisi Timur juga tidak hanya meliputi aspek-aspek fisik dan empirik. Proses mengetahui dan kualitas pengetahuan dalam tradisi Timur selalu melibatkan dimensi metafisis dan berkaitan erat dengan aspek metakosmos - untuk menunjukkan wilayah mikrokosmos dan makrokosmos yang utuh dan terpadu. ${ }^{56}$

Walaupun perennialisme berkait erat dengan tradisi Timur, namun Nasr juga mengakui konsep pengetahuan seperti itu bukanlah monopoli tradisi Timur, tetapi juga tradisi-tradisi lain termasuk tradisi Barat pra-modern. Keterpisahan antara pengetahuan transenden dan pengetahuan profan secara serius terjadi setelah periode renaisance yang menandai era modernisme, khususnya di Barat dengan sistem filsafatnya yang rasional dan sarat dengan semangat naturalistik, empirik, dan hedonistik-materialistik. Namun demikian, Nasr tetap percaya bahwa pada karakternya yang asli (genuine), tradisi Barat pun - sebagaimana tradisi-tradisi lain - mengandung watak spiritual di samping rasional. Itulah sebabnya, ketika hendak melakukan kritiknya terhadap Barat, Nasr mengatakan bahwa kita juga harus mengangkat kembali the millennial tradition of the west itself. Tradisi tersebut adalah tradisi yang sudah beratus-ratus tahun membentuk peradaban Barat sendiri - yang tidak lain adalah tradisi universal dan permanen (abadi), yang dikenal dengan istilah "kebijakan abadi" (the perennial wisdom) atau sophia perennis, sanatana dharma, atau al-hikmah alkhalidah. ${ }^{57}$

${ }^{56}$ Seyyed Hossein Nasr, Knowledge ..., hlm. Vii.

${ }^{57}$ Ibid., hlm. viii. Perlu dicatat bahwa istilah philosophia perennis - yang dalam bahasa Inggris diterjemahkan dengan perennial philosophy - pertama kali dipakai oleh Agostino Steuco (1497-1548), seorang filsuf yang sekaligus teolog Renaissance, yang beraliran Augustinus. Dalam karyanya de perennial philosophia, Steuco -- yang dipengaruhi oleh tokoh-tokoh seperti Ficino, Pico, dan Nicolas - menggunakan istilah itu dalam konteks filsafat dan teologi yang tidak terbatas pada salah satu aliran pemikiran saja. Seperti para pendahulunya, ia memegang ide tentang kehadiran suatu kebijakan kuno (an ancient wisdom) yang sudah ada sejak munculnya sejarah kehidupan manusia. Dalam bagian lain, ditegaskan bahwa kebijakan (bikmah, wisdom) pada awalnya merupakan asal yang bersifat Ilahiyah, pengetahuan suci yang diberikan Tuhan kepada Adam. Oleh kebanyakan manusia, pengetahuan itu setahap demi setahap diabaikan dan dianggap sebagai sebuah mimpi. Bagi Steuco, "agama dan filsafat yang benar adalah yang memiliki tujuan theosis. Artinya, sudah ada sejak awal sejarah kehidupan manusia dan dapat diperoleh, baik melalui ekspresi kebenaran itu secara historik dalam aneka tradisi ataupun melalui intuisi intelektual dan kontemplasi filosofis". 
Dalam konteks inilah, Nasr ingin agar nilai permanen pengetahuan yang sudah teruji dari masa ke masa - ditawarkan sebagai alternatif. "Perennial wisdom" atau filsafat perennial tersebut oleh Nasr sering diberi istilah dengan "tradisi" - yang kadang-kadang ditulisnya dengan " $T$ " atau dengan tambahan predikat seperti "tradisi permanen" dan "tradisi universal". Dalam konteks agama-agama, "tradisi" ini dapat disepadankan dengan istilah-istilah dalam agama, seperti Hindu dan Budha, Islam, dan Taoisme, seperti Dharma, al-Din, dan Tao.

Karena filsafat perennial memandang segala yang ada ini sebagai turunan dari Yang Absolut, maka ia selalu menegaskan bahwa dalam segala sesuatu terdapat hakikat. ${ }^{58}$ Oleh karena itu, dalam mendekati agama, filsafat perennial selalu menghubungkan dengan substansinya, yakni inti ajaran agama yang keberadaannya ada di balik bentuk formalnya. Substansi ini bersifat transenden tetapi sekaligus juga immanen. Ia transenden karena substansi agama sulit didefinisikan dan tidak terjangkau kecuali melalui prediketnya. Namun begitu, agama juga immanen karena sesungguhnya hubungan antara prediket dan substansi tidak mungkin terpisahkan. ${ }^{59}$

Melalui pembedaan antara "Yang Hakiki" dengan "yang manifestasi" itulah yang menjadikan filsafat perennial perlu memberikan perhatian pada agama dalam kenyataan trans-historis. Perhatian ini, tidak lain, merupakan usaha untuk mendapatkan kunci memahami agama-agama yang sangat kompleks dan penuh teka-teki yang tidak pernah bisa diduga maknanya jika hanya dilihat secara historis dan eksoteris. Dengan demikian, konsep agama yang dihadirkan melalui pendekatan ini menjadi cukup luas mencakup tipe agama yang asli dan yang historis, yang Semit dan yang India, yang mistik dan yang "abstrak". Tentunya, wilayah agama yang dikaji menjadi sangat luas dan mendalam karena terkait dengan yang essensial agama. ${ }^{60}$

Oleh karenanya, menurut Nasr, pendekatan ini sama sekali tidak meniadakan adanya aspek-aspek sosial dan psikologis dari agama. "Hanya saja pendekatan ini menolak adanya reduksi agama ke dalam manifestasimanifestasi yang bersifat sosial ataupun psikologis.". Hal ini karena "agama datang dari perkawinan antara Norma Ilahiah dan kolektivitas manusia yang ditakdirkan untuk menerima jejak dari norma itu. Dari perkawinan itu, lahir

\footnotetext{
${ }^{58}$ Komaruddin Hidayat \& Muhammad Wahyuni Nafis, Agama Masa Depan; Perspektif Perennial, (Jakarta: Paramadina, 1995), hlm. 4.

${ }^{59}$ Ibid., hlm. 53.

${ }^{60}$ Ibid., hlm. 187.
} 
agama seperti terlihat di dunia ini, di antara budaya dan bangsa yang berbedabeda". ${ }^{61}$

Menurut Nasr, "dimensi dalam adalah kunci untuk memasuki makna essensial agama dan agama-agama". ${ }^{2}$ Pada tingkat ini juga, pendekatan perennialisme mampu menemukan "kesatuan transenden" yang melandasi perbedaan bentuk dan praktek agama, suatu "kesatuan" yang terletak dalam kebenaran essensial agama di jantung agama-agama.

Titik tolak pendekatan perennialisme pada struktur metafisika agama inilah yang memungkinkan pendekatan ini mampu memberikan apresiasi yang tepat pada setiap rincian dari suatu tradisi sakral sebagai yang berasal dari sorga dan untuk itu harus diperlakukan dengan hormat (ta'rim) sebagaimana mestinya. Oleh karenanya, dalam pendekatan ini, sepenuhnya diakui jenius spiritual tertentu dari setiap agama dengan keunikannya, dan menekankan bahwa keistimewaan-keistimewaan itu betul-betul bukti Asal Mula Yang Transedental dari setiap agama dan realitas dari pola dasarnya dalam Intelek Ilahi. ${ }^{63}$ Oleh karenanya, dalam pendekatan ini, bisa dikenal cara memahami agama di luar kepenganutannya secara simpatik tanpa menghilangkan makna absolut, yang merupakan sesuatu yang unik dan khusus dari kehidupan keagamaan, yang mencerminkan suatu kenyataan bahwa agama datang dari Yang Absolut.

Tawaran pemikiran ini sesungguhnya telah mentradisi dalam pemikiran para tokoh tasawuf-falsafi mulai Abu Manshur al-Hallaj dan 'Abd al-Karim alJili dalam konsep mereka tentang wahdat al-adyan.

\section{Simpulan}

Tentunya, terlepas dari berbagai kekurangan intrinsik yang dimiliki oleh pendekatan ini, tawaran pemikiran Seyyed Hossein Nasr bisa melengkapi pemahaman kaum beragama tentang agama secara utuh di tengah-tengah fenomena politik identitas agama.

Paling tidak, pokok persoalan yang bisa "disentuh" oleh tawaran pemikiran Seyyed Hossein Nasr bagi pemahaman kaum beragama tentang agama secara utuh adalah tradisi sufisme bisa memberi landasan spiritual tentang Asal Ilahiah pola keberagamaan tidak terjebak dalam pola pemahaman keagamaan yang bersifat ekskusif []

\footnotetext{
${ }^{61}$ Seyyed Hoseein Nasr, "Philosophia Perennis" ..., hlm. 185.

${ }^{62}$ Seyyed Hossein Nasr, "The Interior Life" ..., hlm. 53.

${ }^{63}$ Seyyed Hossein Nasr, "Philosophia Perennis", ..., hlm. 189.
} 


\section{Daftar Pustaka}

Ahmad Fuad al-ahwani, Filsafat Islam, disunting oleh Sutardji Calzoum Bachri, (Jakarta: Pustaka Firdaus, 1988).

Audy WMR Wuisang dalam http://audywuisang. blogspot.com/2007/05/perda-syariat-vs-nasionalisme-indonesia.html

C. A. Qadir, Filsafat dan Ilmu Pengetabuan dalam Islam, diterjemahkan oleh Hasan Basri, (Jakarta: YOI, 1989).

Ismail Hasani, et.all., Radikalisme Agama di Jabodetabek \& Jawa Barat Implikasinya terhadap Jaminan Kebebasan Beragama/Berkeyakinan, (Jakarta: SETARA Institute, 2011).

Jamhari dan Jajang Jahroni, Gerakan Salafi Radikal di Indonesia, (Jakarta: Rajawali Press, 2004).

Komaruddin Hidayat \& Muhammad Wahyuni Nafis, Agama Masa Depan; Perspektif Perennial, (Jakarta: Paramadina, 1995)

Guillermo O’Donnell \& Philippe C Schmitter. (1986). Transitions from authoritarian rule. Baltimore: The Johns Hopkins University Press.

Majalah Tempo edisi 8, 14 Mei 2006.

M. Amin Abdullah, "Tinjauan Antropolgis-Fenomenologis Keberagamaan Manusia: Pendekatan Filsafat Untuk Studi Agama-Agama", dalam Abdurrahman, dkk (ed.), 70 Tabun H. A. Mukti Ali: Agama dan Masyarakat, (Yogyakarta: IAIN Sunan Kalijaga Press, 1993).

M. Amin Abdullah, Studi Agama: Pendekatan Agama, Makalah dalam Peringatan 100 Tahun Perlemen Agama-Agama se-Dunia dan Kongres Nasional I Agama-Agama di Indonesia (Yogyakarta: 11 - 12 Oktober 1993).

M. Imadadun Rahmat dan Khamami Zada, "Agenda Politik Gerakan Islam Baru", dalam Jurnal Tashwirul Afkear, Edisi Khusus [Pergulatan Identitas Islam: Pergulatan Islamisme dan Islam Progresif], Jakarta: Depag RI \& Lakpesdam NU).

Murthada Muthahhari, Tema-Tema Filsafat Islam, diterjemahkan oleh A. Rifa'I Hasan, (Bandung: Yayasan Muthahhari, 1993).

Noorhaidi Hasan, Laskar Jibad: Islam, Militancy and the Quest for Identity in Post-New Order Indonesia. (Ithaca, New York: Southeast Asia Program, Cornell University, 2006).

Nurrohman dan Marzuki Wahid, "Politik Formalisasi Syari'at Islam dan Fundamentalisme Islam", dalam Istiqro', Vol. 01, No. 01, 2002. 
Osman Bakar, "Masalah Metodologi dalam Sains Islam”, dalam Taubid \& Sains; Esai-Esai tentang Sejarah dan Filsafat Sains Islam, diterjemahkan oleh Yuliani Liputo, (Bandung: Pustaka Hidayah, 1994)

Peter Mandaville, Global Political Islam, (London \& New York: Routledge, 2007).

Seyyed Hossein Nasr, "Pengantar", dalam Mehdi Ha'iri Yazdi, Ilmu Hudhuri; Prinsip-Prinsip Epistemologi dalam Islam, diterjemahkan oleh Ahsin Muhammad, (Bandung: Mizan, 1994).

Seyyed Hossein Nasr, "Theology, Philosophy, and Spirituality", dalam Seyyed Hossein Nasr, Islamic Spiritualit: Manifestation, (New York: Crossroad, 1991).

Seyyed Hossein Nasr, "Hubungan antara Filsafat dan Tasawuf: Kasus Kultur Persia", diterjemahkan oleh Ihsan Ali-Fauzi, dalam Jurnal al-Hikmah, No. 5, Maret-Juni 1992.

Seyyed Hossein Nasr, Science and Civilization in Islam, (New York: New American Library, 1970).

Seyyed Hossein Nasr" Theology, Philosophy, and the Spirituality", dalam Seyyed Hossein Nasr (ed), Islamic Spirituality: Manifestation, (New York: Crossroad, 1991).

Seyyed Hossein Nasr, Spiritualitas dan Seni Islam, diterjemahkan oleh Sutejo, (Bandung: Mizan, 1993).

Seyyed Hossein Nasr, Islam dalam Cita dan Fakta, diterjemahkan oleh Abdurrahman Wahid dan Hasyim Wahid, (Jakarta: LEPPENAS, 1981), hlm. 1.

Seyyed Hossein Nasr, "Hubungan antara Intelek dan Intuisi dari Perspektif Islam", dalam Salem Azzam (ed), Islam dalam Masyarakat Kontemporer, diterjemahkan oleh Hamid L. A. Basalamah, (Bandung: Gema Risalah, 1988).

Seyyed Hossein Nasr, Tentang Istilah 'Aql, Intelek, dan Akal, dalam Jurnal al-Hikmah, No. 5, Ramadhan - Dzulqa'idah 1412 / Maret-Juni 1992.

Seyyed Hossein Nasr, Knowledge and the Sacred, (Edinburgh: Edinburgh Univ. Press, 1981).

Seyyed Hossein Nasr, Knowledge and the Sacred, (Edinburgh: Edinburgh Univ. Press, 1980).

Seymour Martin Lipset. (1981). Political man; The social bases of politics. Maryland: Baltimore. 